\title{
Estimation of the Soil Saturated Hydraulic Conductivity and Soil Sorptivity of Terraced Soil Using Four-Term Expansions of the Haverkamp Model
}

\author{
Deniz YILMAZ ${ }^{* 1}$ \\ ${ }^{1}$ Munzur Üniversitesi, Mühendislik Fakültesi, İnşaat Mühendisliği Bölümü, \\ Tunceli
}

Geliş tarihi: 28.06 .2021

Kabul tarihi: 13.09 .2021

\begin{abstract}
Uzunçayır water retention Dam is located in the Tunceli province. This semi-arid mountainous region in eastern Turkey is prone to erosion. To combat this phenomenon, terraces along the edge of the Munzur University campus were built on sloping ground with pine plantations. The objective is twofold, on the one hand to mitigate soil erosion and protect the dam from sediments deposits, and on the other hand to promote the infiltration of rainwater and the vegetation of the sloping soil. However, the so-called ecofunctions of the terraces over the time are not proven. Monitoring the infiltration capacities of the terraces over time and space will allow a better understanding of their contribution to the hydrology of the watershed and their effect on soil erosion. The Beerkan infiltration technique offers simple and inexpensive experimental protocols. In addition, treatment methods are constantly improving. More recently, the four-term expansion of the implicit Haverkamp cumulative infiltration equation has been proposed. This complicated but robust formulation was used in this study to estimate the soil sorptivity $S$ and saturated hydraulic conductivity $K_{s}$ of terrace soil at Tunceli. The average $K_{s}$ value of studied site was estimated to be $0.0852 \mathrm{~mm} / \mathrm{s}$ with a standard deviation of $0.0112 \mathrm{~mm} / \mathrm{s}$. The soil sorptivity values were more extensive with mean value of $2.1227 \mathrm{~mm} / \mathrm{s}^{0.5}$ and a standard deviation of $0.5855 \mathrm{~mm} / \mathrm{s}^{0.5}$. The fit of the model used was perfect, showing that fast and robust estimation of $S$ and $K_{s}$ are possible using the new model.
\end{abstract}

Keywords: Beerkan infiltration, Terrace soil, Inverse solution, Soil hydraulic properties

\section{Haverkamp Modelin 4 Terimli Uzantısını Kullanılarak Teras Zeminin Doygun Hidrolik İletkenlik ve Sorptivite Tayini}

$\ddot{\mathbf{O z}}$

Uzunçayır su tutma barajı Tunceli ilinde bulunmaktadır. Türkiye'nin doğusundaki bu yarı kurak dağlık bölge erozyona eğilimlidir. Bu fenomenle mücadele etmek için Munzur Üniversitesi kampüsü sınırlarına boyunca, eğimli yamaçlara teraslar inşa edilmiştir ve çam ağaçları dikilmiştir. Amaç iki yönlüdür, bir yandan toprak erozyonunu önlemek ve barajı sediment birikintilerinden korumak, diğer yandan yağmur suyunun sızmasını ve eğimli toprağın bitki örtüsünü teşvik etmektir. Ancak terasların zaman içindeki sözde eko-fonksiyonları kanıtlanamamıştır. Terasların zaman ve mekâna göre infiltrasyon kapasitelerin

*Sorumlu yazar (Corresponding author): Deniz YILMAZ, dyilmaz@munzur.edu.tr 
izlenmesi, bunların havza hidrolojisine katkılarını ve toprak erozyonu üzerindeki etkilerinin daha iyi anlaşılmasını sağlayacaktır. Beerkan infiltrasyon tekniği basit ve ucuz deneysel protokoller sunar. Ayrıca, bu tür verilerin analiz yöntemleri sürekli olarak gelişmektedir. Son zamanlarda, Haverkamp'ın implisit kümülatif infiltrasyon denkleminin dört terimli uzantısı önerildi. Bu karmaşık fakat sağlam formülasyon, bu çalışmada Tunceli'deki teras toprağının zemin sorptivitesini ve doymuş hidrolik iletkenliğini tahmin etmek için kullanılmıştır. Çalışılan alanın ortalama $K_{s}$ değeri $0,0112 \mathrm{~mm} / \mathrm{s}$ ve standart sapma $0,0852 \mathrm{~mm} / \mathrm{s}$ olarak tahmin edildi. Zeminin sorptivitesi $S 2,1227 \mathrm{~mm} / \mathrm{s}^{0,5}$ ortalama değeri ve $0,5855 \mathrm{~mm} / \mathrm{s}^{0,5}$ standart sapması ile belirlenmiştir. Kullanılan modelin deneysel verileri ile uyumu mükemmeldi. Yeni model kullanılarak $S$ ve $K_{s}^{\text {' }}$ nin hızlı ve sağlam bir şekilde tahmin edilmesinin mümkün olduğunu gösterdi.

Anahtar Kelimeler: Beerkan infiltrasyon, Teras zemin, Ters yöntem, Zemin hidrolik özellikleri

\section{INTRODUCTION}

Arid and semi-arid region are more prone to erosion phenomena due to the increase in heavy precipitations events [1]. Several studies on soil erosion in Turkey have observed these phenomena [2-4]. The terrace reduces kinetic energy of runoff water and promote the infiltration into the soil [5] and thus reduce the soil erosion. Greening application on terrace soils such as trees promote the infiltration through their roots systems. Spatial and temporal monitoring of the terrace properties is mainly done by observation of soil quality and plant growth [6-7], but the soil saturated hydraulic conductivity $K_{s}$ and soil sorptivity $S$ are very rarely measured and only a few studies have investigated this point [8-9]. In Turkey, the hydraulic properties of the terraces are almost never measured. The main reason is that equipment transport at field, time and costs are often break on monitoring terrace hydraulic properties.

In the last decade, the development of experimental protocols as Beerkan infiltration experiments has made it possible to perform infiltration experiments quickly and cheaply [10]. For the processing of the experimental infiltration data, the two terms expansions [11] and Beerkan Estimation of Soil Transfer parameter (BEST) methods were widely used [12-14]. Recently and based on the work of Rahmati et al. [15], MoretFernandez et al. [16] proposed the four terms expansion of the Quasi Exact Implicit (QEI) infiltration formulation [11]. The latter is more accurate, but also more difficult to implement.
This paper proposes the assessment of infiltration capacity of terrace soil of Munzur University campus by estimating the saturated soil hydraulic conductivity $K_{s}$ and the soil sorptivity $S$ using 4 terms expansions of QEI formulation. For this purpose, a specific algorithm was coded using lsrqsolve function of Scilab free software [17]. A total of 8 beerkan infiltrations experiments and soils sampling were performed in terrace of Munzur University. Experimental Beerkan data were treated to estimate $K_{s}$ and $S$.

\section{MATERIAL AND METHOD}

\subsection{Theory}

Haverkamp et al. [11] proposed the implicit analytical quasi exact infiltration (QEI) as follow (Equations 1-2):

$$
\begin{aligned}
& \frac{2 \Delta K^{2}}{S^{2}} t=\frac{1}{1-\beta}\left(\frac{2 \Delta K}{S^{2}}\left(I_{3 D}(t)-A S^{2} t-K_{i} t\right)-\right. \\
& \left.\ln \left(\frac{e^{\frac{2 \beta \Delta K}{S^{2}}\left(I_{3 D}(t)-A S^{2} t-K_{i} t\right)}+\beta-1}{\beta}\right)\right) \\
& A=\frac{\gamma}{r\left(\theta_{S}-\theta_{i}\right)}
\end{aligned}
$$

Where $t$ (T) is the time, $S$ the soil sorptivity $\left(\mathrm{L} \mathrm{T}^{-0.5}\right), I_{3 D}$ is the three-dimensional cumulated infiltration (L), $K_{i}$ is the initial soil hydraulic conductivity $\left(\mathrm{L} \mathrm{T}^{-1}\right), \Delta K$ is the difference between the saturated $K_{s}\left(\mathrm{~L} \mathrm{~T}^{-1}\right)$ and the initial $K_{i}\left(\mathrm{~L} \mathrm{~T}^{-1}\right)$ soil hydraulic conductivity, $\theta_{s}\left(\mathrm{~L}^{3} \mathrm{~L}^{-3}\right.$, field- 
saturated soil water content $), \theta_{i}\left(\mathrm{~L}^{3} \mathrm{~L}^{-3}\right.$, initial soil water content), $r(\mathrm{~L})$ the radius of the infiltration ring. For relatively initial dry soils conditions $\theta_{i}<0.25 \theta_{s}, \gamma$ and $\beta$ are constants considered equal to respectively 0.75 and 0.6 [18]. Although QEI formulation is complex to solve, it has the advantage to be valid for the total infiltration experiment. For practical and simplicity reason, Haverkamp et al. [11] presented two terms expansions of QEI formulation to short and long times as follow (Equations 3-4):

$$
\begin{aligned}
& I_{2 T}(t)=S \sqrt{t}+\left(\frac{2-\beta}{3} K_{s}+A S^{2}\right) \cdot t \\
& I_{2 T_{+\infty}}(t)=K_{s} \cdot t+\frac{S^{2}}{2 \Delta K(1-\beta)} \ln \frac{1}{\beta}
\end{aligned}
$$

The use of the 2 terms expansion formulas especially with BEST methods are quite common [19]. However, the steady state must be reach and the transient formulation is only valid for short time. For relatively dry initial soil condition, where $K_{i} \sim 0$, Rahmati et al. [18] applied the Taylor series up to third order in power of $t^{0.5}$ to the QEI formulation (Equation 1) and presented the three terms approximate expansion as below (Equations 5):

$$
I_{3 T}(t)=I_{2 T}(t)+\frac{1}{9}\left(\beta^{2}-\beta+1\right) \frac{K_{s}^{2}}{S} \cdot t^{\frac{3}{2}}
$$

Similarly, Moret-Fernandez et al. [16] proposed the 4-terms expansions respectively as follow (Equations 6):

$$
I_{4 T}(t)=I_{3 T}(t)+\frac{2}{135}(\beta-2)(\beta+1)(1-2 \beta) \frac{K_{s}^{3}}{S^{2}} \cdot t^{2}
$$

This formulation is almost valid from beginning of the infiltration process to the steady state attainment. The deviation from the QEI formulation appears after very long times which are in practice never reached in the field. Therefore, the 4-terms formula presents the advantage of avoiding transient time complicated iteration procedure which is used in the 2 terms formula.

\subsection{Studied Site}

The studied terrace soil is located at the campus of Munzur University in Turkey (Figure 1). For struggle erosion, pine trees were planted on the terrace. Long term goal aims to monitor hydraulics properties of the terrace section and effect of tree growth on soil structural properties and infiltration capacity. The studied soil is a rectangle surface of 15 meters longer and 3 meters width. The textural class of the soil is loamy sand.

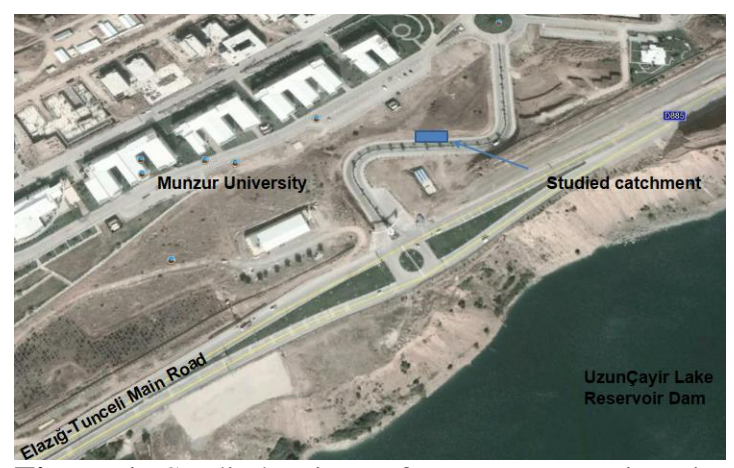

Figure 1. Studied site of Munzur University Campus, google maps picture (2019)

Beerkan infiltration experiments and soil sampling were performed on 25-26 November 2019 (Figure 2).

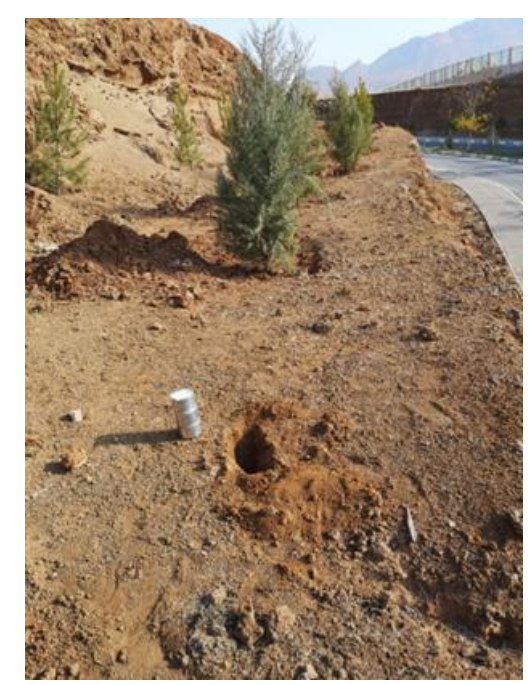

Figure 2. Terrace soil plot studied with black pine tree 
Estimation of the Soil Saturated Hydraulic Conductivity and Soil Sorptivity of Terraced Soil Using Four-Term Expansions of the Haverkamp Model

The soil specific density was measured with the pycnometer method to $2.50 \mathrm{~g} . \mathrm{cm}^{-3}$. The gravimetric water content was measured at three points (Figure 3) and mean value of $5.96 \%$ of dry mass was considered. For each Beerkan experiments, soil sampling was collected to determine the soil bulk density. The physical properties of studied soil are presented in Table 1.

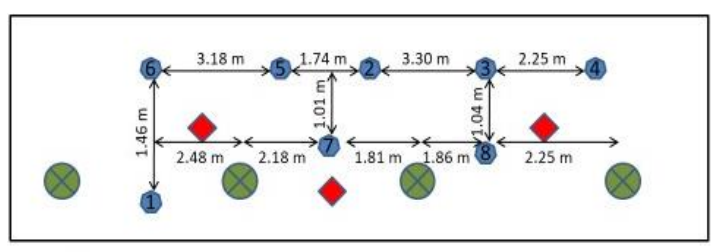

- Infiltration point and bulk density measurement

Black pine tree

Soil water content profile

Figure 3. Soil sampling and Beerkan experiments

\subsection{Beerkan Experiments and Treatment}

At total of 8 Beerkan experiments were performed with a ring devise of $50.85 \mathrm{~mm}$ in radius. The cylinder ring was positioned at the soil surface and inserted to a depth of $1 \mathrm{~cm}$ to avoid lateral loss of ponded water. Several doses of water of same volume were prepared. The first dose was poured into the cylinder at time zero and the elapsed time required to complete infiltration was recorded. Then, the second dose was poured into the cylinder, and the time required to infiltrate was measured (in cumulative terms). This procedure was repeated for a series of 20 known volumes, the volumes were divided by the ring surface to compute the cumulative height of infiltrated water, this last being reported as a function of time to build the cumulative infiltration curves. Note that the ponder water height inside of the ring must not exceed 2-3 $\mathrm{mm}$ to respect the negative or null pressure head assumption made for the development of QEI formulation.
Table 1. Initial gravimetric water content and dry bulk density measurements

\begin{tabular}{|c|c|c|c|c|}
\hline $\begin{array}{c}\text { Water } \\
\text { profil }\end{array}$ & Soil depth & $\omega_{\mathrm{i}}[\%]$ & Beerkan & $\begin{array}{c}\text { Bulk } \\
\text { density }\end{array}$ \\
\hline \multirow{3}{*}{ Point 1} & $0-5 \mathrm{~cm}$ & 0,0420 & ID & {$\left[\mathrm{g} . \mathrm{cm}^{-3}\right]$} \\
\cline { 2 - 5 } & $5-10 \mathrm{~cm}$ & 0,0667 & 1 & 1,379 \\
\cline { 2 - 5 } & $10-15 \mathrm{~cm}$ & 0,0727 & 2 & 1,556 \\
\hline \multirow{3}{*}{ Point 2 } & $0-5 \mathrm{~cm}$ & 0,0560 & 3 & 1,455 \\
\cline { 2 - 5 } & $5-10 \mathrm{~cm}$ & 0,0695 & 4 & 1,336 \\
\cline { 2 - 5 } & $10-15 \mathrm{~cm}$ & 0,0891 & 5 & 1,271 \\
\hline \multirow{3}{*}{ Point 3 } & $0-5 \mathrm{~cm}$ & 0,0339 & 6 & 1,262 \\
\cline { 2 - 5 } & $5-10 \mathrm{~cm}$ & 0,0420 & 7 & 1,605 \\
\cline { 2 - 5 } & $10-15 \mathrm{~cm}$ & 0,0647 & 8 & 1,476 \\
\hline
\end{tabular}

The fitting procedure of $S$ and $K_{s}$ parameter was coded using the Scilab function lsqrsolve (a leastsquares procedure based on the LevenbergMarquardt algorithm [20]). All the experimental data were used for the fitting procedure.

\section{RESULTS AND DISCUSSION}

Cumulated Beerkan infiltration curves from terrace soil of Munzur university campus are illustrated in Figure 4. All infiltration curves present a concave part at the beginning and the steady state was reached for each experiment. The shorter experiment duration was 0.35 hour and the longest duration was 0.55 hour.

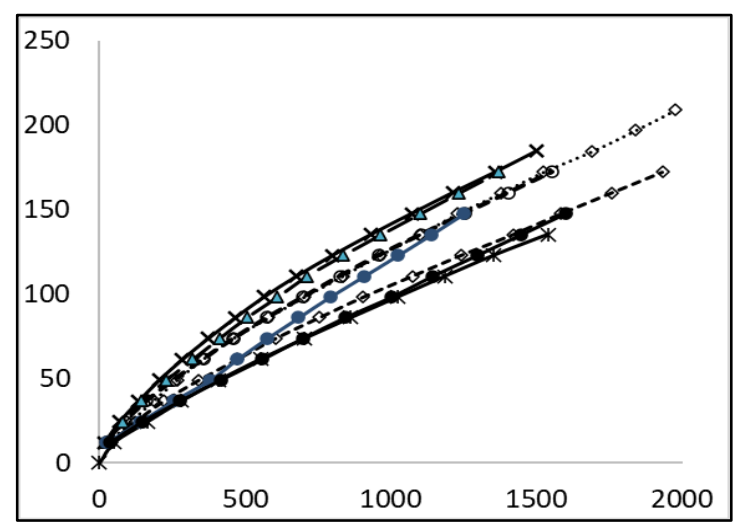

Figure 4. Cumulated Beerkan infiltration curves, horizontal axe belongs to time [s] and vertical axe belongs the cumulated infiltrated water [mm] 
An example of the infiltration curve and 4 terms model adjustment is shown for Beerkan experiment 1 (Figure 5). The model fitting with the experimental data were perfect for all the Beerkan experiments.

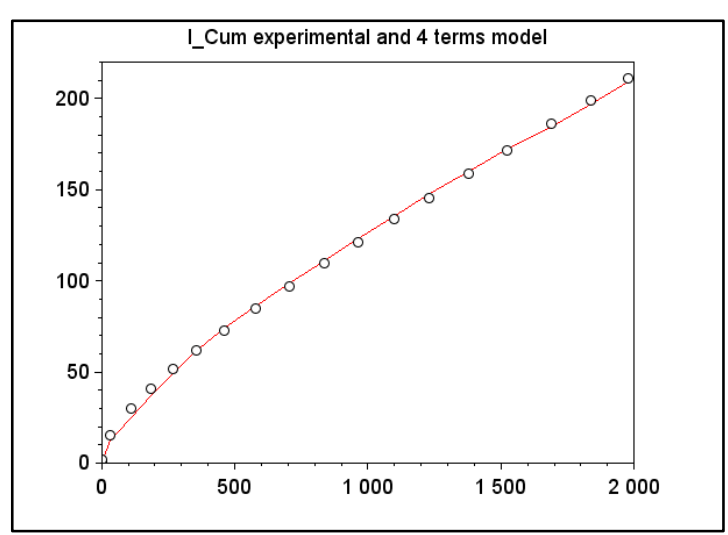

Figure 5. Model (red line) fitting with experimental data (circle), horizontal axe belongs to time [s] and vertical axe belongs the cumulated infiltrated water [mm]

Table 2 summarizes the estimates of $S$ and $K_{s}$ using 4 terms expansion formula and inversion procedure of Scilab. The mean value of sorptivity $S$ and saturated hydraulic conductivity $K_{s}$ of the studied section were respectively $2.1227 \mathrm{~mm} / \mathrm{s}^{0.5}$ with a standard deviation of 0.5854 and 0.0852 $\mathrm{mm} . \mathrm{s}^{-1}$ with a standard deviation of 0.0112 . The highest $K_{s}$ was observed for the more compacted zone (point 7) and meaning the presence of local macropore. Considering the soil variability in situ, the results of $K_{s}$ were quite homogenous. However, $S$ values were more spread out but still in the same range of values. Therefore, if we consider $S$ and $K_{s}$ as an indicator of the infiltration capacity of the terrace soil, the use of 4 terms expansion formula gives a robust estimation of the hydraulic properties of the terrace soil.

Concerning the black tree pine effect, no conclusion can be done at this stage since a longtime monitoring is necessary. In fact, as the trees were planted one month before the experiment, no effect of the roots in the soil matrix is expected. The next campaign infiltration will be conducted for 2021 autumn season and then every two years the site will be monitored using Beerkan experiments to check $K_{s}$ variability in time as done in other studies [21-22].

Table 2. $S\left[\mathrm{~mm} . \mathrm{s}^{-0.5}\right]$ and $K_{s}$ estimates $\left[\mathrm{mm} . \mathrm{s}^{-1}\right]$.

\begin{tabular}{|c|c|c|c|c|}
$\begin{array}{c}\text { Beerkan } \\
\text { ID }\end{array}$ & $\theta_{i}$ & $\theta_{s}$ & $S$ & $K_{s}$ \\
\hline 1 & 0,082 & 0,451 & 1,5784 & 0,0753 \\
\hline 2 & 0,093 & 0,380 & 2,4575 & 0,0835 \\
\hline 3 & 0,087 & 0,420 & 2,9913 & 0,0831 \\
\hline 4 & 0,080 & 0,468 & 2,4163 & 0,0849 \\
\hline 5 & 0,076 & 0,493 & 2,6161 & 0,0956 \\
\hline 6 & 0,075 & 0,497 & 2,0109 & 0,0713 \\
\hline 7 & 0,096 & 0,361 & 1,4078 & 0,1067 \\
\hline 8 & 0,088 & 0,412 & 1,5035 & 0,0808 \\
\hline
\end{tabular}

\section{CONCLUSION}

The soil sorptivity $S$ and saturated hydraulic conductivity $K_{s}$ of terrace soil of Munzur university campus were investigated using 4 terms expansion formula of Haverkamp implicit equation. Results gave consistent results showing homogenous value of $K_{s}$ and slightly more spreadout value for $S$. However, a full hydraulic characterization of the terrace soil such as soil water retention curve and soil hydraulic conductivity curve need the estimation of textural parameter of the soil. For that, pedotransfer function is needed and use of BEST algorithms are more appropriate. The use of 4 terms in comparison to BEST do not require the attainment of the steady-state and therefore is time saving especially when the soil infiltration capacity is low. Also, the fit of the model with experimental data were perfect giving a high confidence to the estimated soil hydraulics parameters. Consequently, Beerkan infiltration experiments can be considered as a robust, less expensive, and rapid method when couple with the 4 terms formulation. However, the terrace effect on soil erosion and reduction of sediment in dam reservoir can be assess by comparison of runoff water mitigation of terrace with slope soils. Further research will be done to investigate the hydraulic effect of terrace on runoff water. 
Estimation of the Soil Saturated Hydraulic Conductivity and Soil Sorptivity of Terraced Soil Using Four-Term Expansions of the Haverkamp Model

\section{REFERENCES}

1. Alexander, L.V., 2016. Global Observed Longterm Changes in Temperature and Precipitation Extremes: A Review of Progress and Limitations in IPCC Assessments and Beyond. Weather and Climate Extremes, 11, 4-16.

2. Berberoglu, S., Cilek, A., Kirkby, M., Irvine, B., Donmez, C., 2020. Spatial and Temporal Evaluation of Soil Erosion in Turkey Under Climate Change Scenarios Using the Paneuropean Soil Erosion Risk Assessment (PESERA) Model. Environmental Monitoring and Assessment, 192(8), 1-22.

3. Ozsoy, G., Aksoy, E., Dirim, M.S., Tumsavas, Z., 2012. Determination of Soil Erosion Risk in the Mustafakemalpasa River Basin, Turkey, Using the Revised Universal Soil Loss Equation, Geographic Information System, and Remote Sensing. Environmental management, 50(4), 679-694.

4. Yuksel, A., Gundogan, R., Akay, A.E., 2008. Using the Remote Sensing and GIS Technology for Erosion Risk Mapping of Kartalkaya Dam Watershed in Kahramanmaras, Turkey. Sensors, 8(8), 4851-4865.

5. Kalkan, B., Taşdemir, C., Gökbulak, F., Tiryaki, O., 2017. Elazı̆̆ Yöresinde Seki Teraslarda Uygun Düşey Aralığın Belirlenmesi. Ormancılık Araştırma Dergisi, 4(2), 121-132.

6. Pekal, K., 2009. Artvin Çoruh Nehri Su Havzasında Erozyon Kontrolü Amaçlı Ağaçlandırma Çalışmalarının Değerlendirilmesi: Sümbüllü ve Salkımlı Yöresi Ağaçlandırma Çalışmaları. Master's Thesis, Artvin Çoruh Üniversitesi.

7. Taysun, A., Ünal, H. B., Şahin, A., Vurgun, H. Z., 2000. Determining the Efficiency of Forward-sloped Bench Terraces on Soil Conservation: The Case of the AydinBozdoğan-Alamut Terracing Area. Turkish Journal of Agriculture and Forestry, 24(6), 729-736.

8. Posthumus, H., Stroosnijder, L., 2010. To Terrace or Not: the Short-term Impact of Bench Terraces on Soil Properties and Crop Response in the Peruvian Andes. Environment,
Development and Sustainability, 12(2), 263-276.

9. Nie, W., Ma, X., Fei, L., 2017. Evaluation of Infiltration Models and Variability of Soil Infiltration Properties at Multiple Scales. Irrigation and Drainage, 66(4), 589-599.

10. Braud, I., De Condappa, D., Soria, J.M., Haverkamp, R., AnguloJaramillo, R., Galle, S., Vauclin, M., 2005. Use of Scaled Forms of the Infiltration Equation for the Estimation of Unsaturated Soil Hydraulic Properties (The Beerkan Method). European Journal of Soil Science, 56(3), 361-374.

11. Haverkamp, R., Ross, P.J., Smettem, K.R.J., Parlange, J.Y., 1994. Three-dimensional Analysis of Infiltration from the Disc Infiltrometer: 2. Physically Based Infiltration Equation. Water Resources Research, 30(11), 2931-2935.

12. Lassabatere, L., Angulo-Jaramillo, R., Soria Ugalde, J.M., Cuenca, R., Braud, I., Haverkamp, R., 2006. Beerkan Estimation of Soil Transfer Parameters Through Infiltration Experiments-BEST. Soil Science Society of America Journal, 70(2), 521-532.

13. Yilmaz, D., Lassabatere, L., Angulo-Jaramillo, R., Deneele, D., Legret, M., 2010. Hydrodynamic Characterization of Basic Oxygen Furnace Slag Through an Adapted BEST Method. Vadose Zone Journal, 9(1), 107-116.

14. Bagarello, V., Di Prima, S., Iovino, M., 2014. Comparing Alternative Algorithms to Analyze the Beerkan Infiltration Experiment. Soil Science Society of America Journal, 78(3), 724-736.

15. Rahmati, M., Latorre, B., Lassabatere, L., Angulo-Jaramillo, R., Moret-Fernández, D., 2019. The Relevance of Philip Theory to Haverkamp Quasi-exact Implicit Analytical Formulation and its Uses to Predict Soil Hydraulic Properties. Journal of Hydrology, 570, 816-826.

16. Moret-Fernández, D., Latorre, B., López, M. V., Pueyo, Y., Lassabatere, L., AnguloJaramilo, R., Rahmati, M., Tormo, J., Nicolau, J.M., 2020. Three-and Four-term Approximate Expansions of the Haverkamp Formulation to Estimate Soil Hydraulic Properties from Disc 
Infiltrometer Measurements. Hydrological Processes, 34(26), 5543-5556.

17. Campbell, S.L., Chancelier, J.P., Nikoukhah, R., 2010. Modeling and Simulation in SCILAB. In Modeling and Simulation in Scilab/Scicos with ScicosLab 4.4. Springer, New York, NY, 73-106.

18. Angulo-Jaramillo, R., Bagarello, V., Di Prima, S., Gosset, A., Iovino, M., Lassabatere, L., 2019. Beerkan Estimation of Soil Transfer Parameters (BEST) Across Soils and Scales. Journal of Hydrology 576, 239-261.

19. Yilmaz, D., 2021. Alternative $\alpha^{*}$ Parameter Estimation for Simplified Beerkan Infiltration Method to Assess Soil Saturated Hydraulic Conductivity. Eurasian Soil Science, 54(7).

20. Marquardt, D., 1963. An Algorithm for LeastSquares Estimation of Nonlinear Parameters. SIAM Journal on Applied Mathematics, 11,431-441.

21. Yilmaz, D., Lassabatere, L., Angulo-Jaramillo, R., Deneele, D., Legret, M., 2013. Influence of Carbonation on the Microstructure and Hydraulic Properties of a Basic Oxygen Furnace Slag. Vadose Zone Journal, 12(2), vzj2012-0121.

22. Yilmaz, D., Cannavo, P., Séré, G., VidalBeaudet, L., Legret, M., Damas, O., Peyneau, P.E., 2018. Physical Properties of Structural Soils Containing Waste Materials to Achieve Urban Greening. Journal of Soils and Sediments, 18(2), 442-455. 
